\title{
PROXIMATE COMPOSITION AND THE FUNCTIONAL PROPERTIES OF DEFATTED SEED AND PROTEIN ISOLATES OF KARGO (Piliostigma reticulatum) SEED
}

Akin-Osanaiye $\mathrm{BC}^{1}$. Agbaji $\mathrm{AS}^{2 *}$, ${\text { Agbaji } \mathrm{EB}^{3} \text { and } \mathrm{OM} \text { Abdulkadir }}^{4}$.

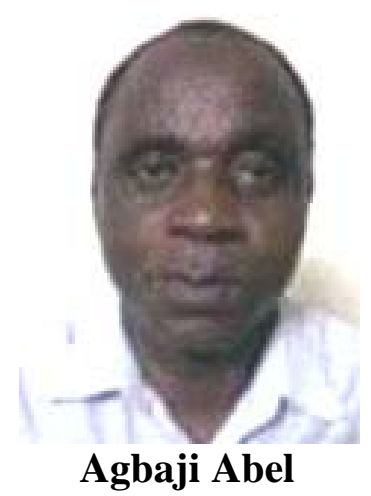

*Corresponding author email: tou_femi@yahoo.com

${ }^{1}$ Chemistry Department, University of Abuja, Abuja, Nigeria.

${ }^{2}$ National Research Institute for Chemical Technology, Private Mail Bag 1052, Zaria, Kaduna State, Nigeria

${ }^{3}$ Chemistry Department Ahmadu, Bello University, Zaria, Kaduna State, Nigeria

${ }^{4}$ Biochemistry Department, Ahmadu Bello University, Zaria, Kaduna State, Nigeria 


\section{ABSTRACT}

The proximate composition of the Kargo seeds and the physico-chemical properties of the seed oil have been determined. Matured dried seeds were collected. They were then dehusked and pulverized into a fine powder and kept in air tight sample bottle for further analysis. Functional properties of the defatted sample and its protein isolate were also determined. The seed is rich in both crude protein $(40.4 \%)$ and lipid $(27.9 \%)$ and, therefore, could be classified as an oil seed. The crude protein for the defatted sample is significantly $(\mathrm{p}<0.05)$ higher than the protein value recorded for the undefatted $(303 \mathrm{~g} / \mathrm{kg})$. At room temperature the lipid extract was a liquid. The lipid is a clear golden yellow colour with low acid value (0.5\%), but high saponification value of $205.1 \mathrm{mg} \mathrm{KOH} / \mathrm{g}$ and iodine value of 103.9. The elemental analysis carried out on both the undefatted and the defatted seed shows that, the seed is a good source of potassium, phosphorus, magnesium and calcium. The defatted flour samples recorded a higher values for all the mineral elements determined except for the manganese which though very minute in quantity was observed to be doubled in the undefatted sample. The value recorded for both potassium and magnesium are significantly higher $(\mathrm{p} \leq 0.05)$ in the defatted sample than in the undefatted sample. Both the defatted flour and protein isolate show good foaming, emulsion and water binding properties. The defatted sample has a low water and oil binding capacity (1.84 and $0.41 \%$, respectively) compared to the values recorded for the protein isolates $(2.77$ and $0.94 \%$ respectively). There is a significant difference $(\mathrm{p} \leq 0.05)$ in the values obtained for the foaming stability of the defatted flour sample (3.92\%) and the protein isolate $(0.01 \%)$. This indicates that Kargo seed protein isolate with estimated protein content of $86.0 \%$ and good functional properties has a potential for dietary improvement in the food industries.

Key words: Kargo, Proximate, Isolates, Functional properties 


\section{INTRODUCTION}

Kargo (Piliostigma reticulatum) is a leguminous medium-sized tree which grows wild in the tropics and is one of the commonest species of Piliostigma (Hochst) in the northern part of Nigeria [1,2] where it is locally known as Kargo or Kalgo. The large quantity of seeds from this tree is not currently being utilized except for cattle that eat the pods. Indeed, several tonnes of Kargo seeds are wasted annually in Nigeria.

Protein deficiency is the prevalent form of malnutrition in developing countries [3]. One of the ways to increase the protein supply is to make more plant proteins available for human consumption and to develop the production of unconventional protein for animal food [3]. The constantly rising cost of conventional protein foods, particularly animal proteins, makes it likely that new sources of proteins will be increasingly exploited in developing countries. This search for nutritionally balanced foods to make available to a substantial proportion of the population has stimulated investigation into many unusual sources of protein [4]. Indeed, protein isolates have been extensively studied as food and dietary supplements from several oil seeds such as sesame, soy beans, castor lequerella and even wheat-plantain composite flour $[5,6,7,8]$.

The easiest method of separating proteins from the cellular structure of the seed is by extraction with an aqueous solvent though amount of protein extracted depends on $\mathrm{pH}$ and ionic strength of the solvent. For successful utilization in food products, however, the protein should possess a high degree of functionality. Functionality has been defined as any property that affects the utilization of a product $[9,10]$, and this functionality is governed by four major factors, which are colour, flavour (aroma), texture and nutritive value.

There is little or no published information on the chemical composition of Kargo seed, its oil, and the functionality of its protein isolate. This study was, therefore, undertaken to provide information on the proximate composition, the physicochemical properties of the oil and functional properties of the protein isolate from the seeds of Piliostigma reticulatum grown in Nigeria as a basis for their utilization.

\section{MATERIALS AND METHODS}

\section{Materials}

The Kargo seeds were obtained from the surroundings of National Research Institute for Chemical Technology, Zaria, Nigeria. About 500g of the dried seeds were prepared for use by removing the seed husk (dehusking) and the endosperm ground into powder and packaged in a clean dried sample bottle for subsequent analysis. The seed husk was removed by soaking the seed inside water in a container for $30 \mathrm{~min}$. The soft coat was then peeled off using the tip of the finger. 


\section{Sample preparation}

\section{Lipid extraction}

The lipid was extracted from the seed sample by following the method described by Christie [11]. Briefly, exactly 5.0g powdered sample of Kargo seed was accurately weighed into a clean dry previously weighed cellulose thimble and weighed again with degreased cotton wool as cover. Some $150 \mathrm{~mL}$ of petroleum ether $\left(40-60^{\circ} \mathrm{C}\right)$ was poured into a clean dry $250 \mathrm{~mL}$ round bottomed flask containing anti-bumping granules. The flask was then fixed to the Soxhlet extractor which contained the thimble and then placed on a heating mantle with a water source as a coolant. The extraction was carried out for $6 \mathrm{~h}$. The oil was then dried in the oven at $80^{\circ} \mathrm{C}$ for 30 min. The thimble was also taken to the oven and dried under the same condition as the oil to evaporate any residual oil. The oil was weighed and kept for physico-chemical properties analysis. The flour (fat free sample) was used to isolate the protein isolate.

\section{Kargo Protein Isolates}

The protein isolate was obtained using the method described by Terry et al. [12]. Two grammes of the defatted flour were weighed into eight different beakers in order to have enough yields for subsequent analysis. About $100 \mathrm{~mL}$ of $0.1 \mathrm{M} \mathrm{NaOH}$ was added and stirred using a magnetic stirrer for $30 \mathrm{~min}$ at room temperature. Non solubilized materials were removed by centrifugation at $3500 \mathrm{~g}$ for $30 \mathrm{~min}$. The protein in the extract, that is, the supernatant, was precipitated out by drop-wise addition of $0.1 \mathrm{M} \mathrm{HCl}$ until the $\mathrm{pH} 4.5-4.7$ at which it was least soluble was obtained. The protein was recovered by centrifugation at $3500 \mathrm{~g}$ for $20 \mathrm{~min}$, and then dialyzed against distilled water containing $5 \%$ sodium metabisulphite with several changes of water for $48 \mathrm{~h}$ at room temperature. The dialysate was freeze-dried and stored for subsequent analysis.

\section{Analytical methods \\ Proximate Analysis}

The proximate composition of the seeds was carried out using AOAC [13] methods. Crude protein was expressed as percentage nitrogen $\left(\% \mathrm{~N}_{2}\right) \times 6.25$. The defatted sample was also analyzed for protein.

\section{Mineral Analysis}

The seeds were put into solution by wet digestion and the mineral composition was determined using the EEL-type flame photometer for sodium and potassium and a Pye-Unicam atomic absorption spectrophotometer for other elements. Both the undefatted and the defatted seed samples were analyzed for minerals.

\section{Physico-chemical properties}

The physico-chemical properties determined for the Kargo oil includes: saponification value, iodine value, acid value, free fatty acid value, ester value, hydroxyl value, peroxide value and unsaponifiable matter following the methods described by Pearson [14] and Paquot [15]. The $\mathrm{pH}$ of the oil was determined using an EIL 7020 Kent pH meter.

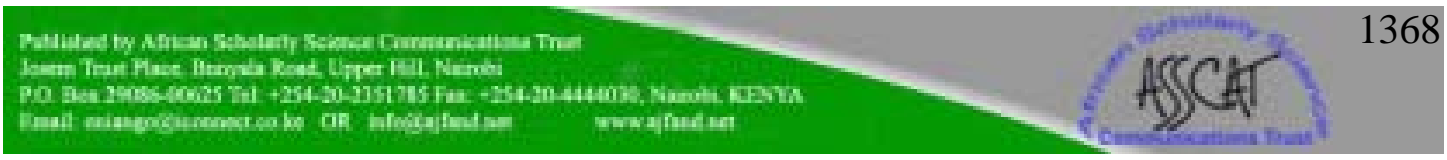




\section{Functional Properties}

The functional properties were determined for both the defatted flour sample and the protein isolates. The functional properties determined are discussed below.

\section{Foaming capacity and stability}

Foaming capacity and stability were studied according to the methods described by Sathe et al. [16]. About 2.0g of the sample was blended for $5 \mathrm{~min}$ with $40.0 \mathrm{~mL}$ distilled water at top speed in a National blender'Tm'. The whipped mixture was transferred into a $100 \mathrm{~mL}$ graduated measuring cylinder. Changes in the foam volume in the cylinder were recorded at intervals of 30,6090 and 120 minutes. For each sample, triplicate measurements were made and the mean values recorded.

Foam stability $=$ Final vol. after $1 \mathrm{~h}-$ initial vol. $\mathrm{X} 100$

Initial vol.

\section{Emulsion Activity and Stability}

Exactly $2.0 \mathrm{~g}$ of the flour sample was placed in a test tube to which $4.0 \mathrm{~mL}$ of refined vegetable oil (Turkey oil) was added, they were thoroughly mixed together with a test-tube mixer. The emulsion formed was centrifuged at $2000 \mathrm{~g}$ for $5 \mathrm{~min}$. The ratio of the emulsion layer to the total height of the whole sample in the centrifuge bottle was calculated as emulsion activity expressed in percentage. The emulsion stability was also determined following the methods described by Okezie and Bello [17]. The same type of mixture was employed but heated at $80^{\circ} \mathrm{C}$ for $30 \mathrm{~min}$ in a water bath. The mixture was cooled under a running tap water for $15 \mathrm{~min}$ and centrifuged at $2000 \mathrm{~g}$ for 5 min. The emulsion stability was calculated using the same method used for emulsion activity. Triplicate determinations were carried out and the mean results taken.

Emulsion activity $=\underline{\text { Height of emulsion layer }} \times 100$

Total height of the whole layer.

\section{Water and oil binding capacities}

This was carried out using the method described by Lin et al. [18] and Okaka and Potter [19]. To $1.0 \mathrm{~g}$ of each sample in the test tubes was added $10 \mathrm{~mL}$ of distilled water for water absorption and Turkey vegetable oil for oil binding. The test tubes were allowed to stand on the bench for $1 \mathrm{~h}$ then centrifuged at $1600 \mathrm{~g}$ for $25 \mathrm{~min}$. Excess water was decanted and the samples were allowed to drain dry. The weight of water absorbed was determined by difference.

Weight of water/oil absorbed =weight of sample + water/oil - weight of sample only Means of triplicate determination was taken.

\section{Least Gelation point}

Fifteen test tubes were arranged with series of sample suspension containing $5.0 \mathrm{~mL}$ of water with specific concentrations varying from $2-30 \%$ at $2 \%$ intervals. The suspensions were gelatinized by boiling for $30 \mathrm{~min}$ with constant stirring. These were allowed to cool for $18 \mathrm{~h}$. Each test tube was then inverted for about $2 \mathrm{~min}$ and the

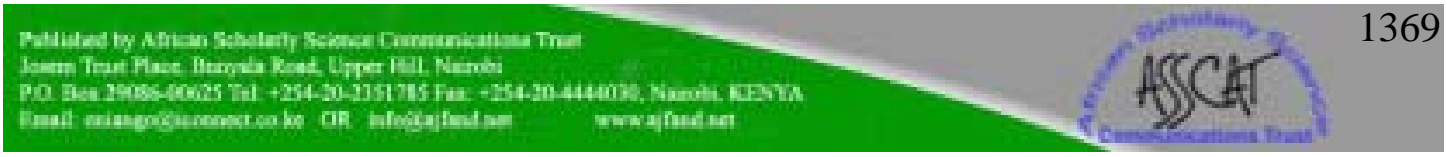


concentration at which the resulting paste did not pour out was taken as the minimum gelation point.

\section{Solubility determination}

About $0.2 \mathrm{~g}$ of finely ground sample was placed in a test tube and $0.5 \mathrm{~mL}$ of distilled water was added to the tube and stirred with a glass rod. This was allowed to stand at room temperature for $5 \mathrm{~min}$. The sample was stirred for another five minutes to enhance solubility using a test tube shaker. This procedure was repeated using hot water, ethanol $(95 \% \mathrm{v} / \mathrm{v})$ and petroleum ether $\left(40-60{ }^{\circ} \mathrm{C}\right)$ in place of distilled (cold) water. The result was recorded as means of triplicate determinations.

\section{Statistical analysis}

Analysis for the significant difference in the results was obtained by Student's $t$ test.

\section{RESULTS}

The results of the proximate composition of the Kargo seed are presented in Table 1. Clearly the seeds contain a high percentage of crude lipid (27.9\%) and the lipid was gold yellow and liquid at room temperature. The crude protein contents of both the undefatted and defatted seeds were $30.3 \%$ and $40.4 \%$, respectively. The difference in these values was significant $(\mathrm{p} \leq 0.05)$. The protein isolate obtained recorded high percentage protein $(86.0 \%)$. However, the seeds had a low moisture content which may be due to its dry state of collection and this may enable the seeds to possess a long storage capability. The mineral content of both the undefatted and defatted Kargo seeds are presented in Table 2. The defatted flour sample has recorded higher values for the entire mineral elements determined except for manganese which, though very minute in quantity, was observed to be doubled in the undefatted sample. The values recorded for both potassium and magnesium are significantly higher $(\mathrm{p} \leq 0.05)$ in the defatted sample than in the undefatted sample.

Data on the physico-chemical properties of the Kargo seed oil are given in Table 3. The oil is liquid at room temperature with a golden yellowish colour. The oil is low in acid and free fatty acid value $(0.5$ and $0.3 \%)$, respectively. Also it is low in peroxide value $(0.8 \%)$ and hydroxyl value $(3.7 \%)$. However, the value recorded for iodine (103.9) and saponification (205.1) are high.

The functional properties of the Kargo defatted seed flour and its protein isolates are presented in Table 4. The defatted sample has a low water and oil binding capacity (1.84 and $0.41 \%$ ), respectively compared to the values recorded for the protein isolates $(2.77$ and $0.94 \%)$, respectively. There is a significant difference $(\mathrm{p} \leq 0.05)$ in the values obtained for the foaming stability of the defatted flour sample (3.92\%) and the protein isolate $(0.01 \%)$. The least gelation point for the defatted sample and the protein isolate were $10.0 \%$ and $6.0 \%$, respectively. However, both the defatted seed flour and the protein isolates are insoluble in cold water, hot water and ethanol investigated. 


\section{DISCUSSION}

The result of the proximate composition clearly showed that the seeds contain high percentage of crude lipid (27.9\%). This value is higher than that reported for soy beans $(19.10 \%)$ [17]. The value obtained for the protein is also higher than values reported for some oil seeds like neem seed (26.66\%) [18]. It is also a good source of potassium, phosphorus, magnesium and calcium. The seed can thus be used as a source of proteins and minerals for animals and humans.

The lipid extracted from the seed is a liquid at room temperature with a golden yellow colour. The high saponification value is an indication that the oil consists of a high proportion of low molecular weight fatty acids while the iodine value indicates the non-drying nature of the oil, though in its native state, it may be too unsaturated for soap manufacturing. Meanwhile, the low hydroxyl value (3.7\%) shows that the oil does not contain either primary or secondary alcohol but is predominantly a normal triacyl glycerol.

The functional properties of the defatted seed sample and its protein isolates as presented in Table 3 showed that the foaming produced by the defatted Kargo seed sample was more stable than that of its protein isolate. Product foam ability is related to the rate of decrease of the surface tension of air/water inter caused by absorption of protein molecules [19]. The water binding capacity of the defatted flour and the protein isolate reported in the present study was lower than what were reported for other flours. Lin et al. [15] reported $130 \%$ water absorption for soy flour and $227.3 \%$ and $196.1 \%$ respectively for two commercial soy proteins concentrates namely, Isopro and promo soy; while Memba et al. (8) reported $65-284 \%$ for wheat/plantain water absorption capacity. The emulsion stability was higher in the protein isolate than in the defatted seed cake. This may be due to the globular nature of the major proteins, which is similar to that of winged bean [13]. Lin et al. [15] reported the emulsion capacities of wheat flour, soy flour, sunflower flour and protein concentrates and isolates from soy and sunflower flours to be in the range of 10.1 to $25.6 \%$ with the exception of sunflower ( $95.1 \%$ oil emulsified). In the present study, the Emulsion stability of the Kargo seed and the protein isolate are higher than these values. Gelation is often an aggregation of denatured molecules and contrary to coagulation where the aggregation is random, gelation involves, the formation of a continuous network which exhibits a certain degree of order. Since gelation is important in food industries because a meal with a low value of least gelation point can be a good thickening agent. Thus, protein isolate is, therefore, a better thickening material than the defatted flour. Therefore the Kargo seed protein isolate can be said to have a good emulsifying property and thus the potential of being used in meat, ice cream, baking and texture improvement in high protein food industries. 


\section{CONCLUSION}

The extraction of lipid from the Kargo seed sample enhanced the proximate and mineral composition of the seed. The seed is rich in both crude protein (40.4\%) and lipid (27.9\%) and, therefore, could be classified as an oil seed. At room temperature the lipid extract was a liquid. The oil could be a good material for soap making. The crude protein for the defatted sample is significantly $(\mathrm{p}<0.05)$ higher than the protein value recorded for the undefatted (30.3\%). The seed flour should be defatted before the preparation of the protein isolate. From the results presented in this work, it appears that Kargo seed is a good source of protein supplement in the food industries for human and animal feed production due to its high protein content $(86.0 \%)$ and the good functional properties of Kargo seed protein isolate. 
Table1: Proximate Composition (\%) of Kargo (Piliostigma reticulatum) seed

\begin{tabular}{|lc|}
\hline \multicolumn{1}{|c|}{ Moisture } & $2.7 \pm 0.1$ \\
Ash & $4.0 \pm 0.1$ \\
Crude lipid & $27.9 \pm 1.1$ \\
Crude protein(undefatted) & $30.3 \pm 3.1^{\mathrm{a}}$ \\
Crude protein(defatted) & $40.4 \pm 3.0^{\mathrm{b}}$ \\
Carbohydrate(by difference) & $25.0 \pm 1.4$ \\
Protein(isolate) & $86.0 \pm 1.2$ \\
\hline
\end{tabular}

Superscript ${ }^{\mathrm{a}}$ and ${ }^{\mathrm{b}}$ means they are significantly $(\mathrm{P} \leq 0.05)$ different.

Table 2: Mineral content $(\%)$ of undefatted and defatted Kargo seed

\begin{tabular}{|lll|}
\hline Mineral & Undefatted & Defatted \\
Potassium & 8.90 & 12.94 \\
Phosphorus & 5.20 & 6.08 \\
Magnesium & 3.77 & 5.89 \\
Calcium & 2.29 & 3.30 \\
Sodium & 0.53 & 0.60 \\
Zinc & 0.02 & 0.03 \\
Manganese & 0.02 & 0.01 \\
\hline
\end{tabular}


Table 3: Some Physico-chemical Properties of Lipid (oil) extract from Kargo (Piliostigma reticulatum) Seed

\begin{tabular}{|l|l|}
\hline Physico-chemical property & Value \\
\hline Acid value $(\%)$ & $0.5 \pm 0.03$ \\
Free fatty acid $(\%)$ & $0.3 \pm 0.01$ \\
Pedine value unit needed $(\mathrm{g} / 100 \mathrm{~g})$ & $103.9 \pm 0.18$ \\
Saponification value $(\mathrm{mgKOH} / \mathrm{g})$ & $0.8 \pm 0.01$ \\
Unsaponificable matter $(\mathrm{mg} / \mathrm{g})$ & $205.1 \pm 0.89$ \\
Ester value unit needed $(\mathrm{mgKOH} / \mathrm{g})$ & $1.4 \pm 0.01$ \\
Hydroxyl value $(\%)$ & $204.5 \pm 0.21$ \\
pH & $3.7 \pm 0.04$ \\
State of oil at room temperature & 5.4 \\
Appearance & Liquid \\
Lovibond reading & Golden yellow \\
& \\
\hline
\end{tabular}


Table 4: Functional Properties of Defatted Seed flour and Protein Isolate of Kargo Piliostigma reticulatum) Seed

\begin{tabular}{|c|c|c|}
\hline Functional property & Defatted Seed flour & Protein Isolate \\
\hline Foaming height $\left(\right.$ Vol. In $\left.\mathrm{cm}^{3}\right)$ & $53.30 \pm 0.14^{\mathrm{a}}$ & $43.00 \pm 0.11^{\mathrm{b}}$ \\
\hline Foaming stability (\% vol. After $1 \mathrm{~h}$. ) & $3.92 \pm 0.14^{\mathrm{a}}$ & $0.01 \pm 0.0^{\mathrm{b}}$ \\
\hline Emulsion activity (\%) & $22.30 \pm 0.28^{\mathrm{a}}$ & $37.00 \pm 0.28^{\mathrm{b}}$ \\
\hline Emulsion stability (\%) & $26.30 \pm 0.14^{\mathrm{c}}$ & $38.10 \pm 0.14^{\mathrm{d}}$ \\
\hline Water binding capacity (g/g) & $1.84 \pm 0.01$ & $2.77 \pm 0.03$ \\
\hline Oil binding capacity (g/g) & $0.41 \pm 0.03$ & $0.94 \pm 0.01$ \\
\hline & $10.00 \pm .17$ & $6.00 \pm 0.07$ \\
\hline Solubility $\left(\mathrm{g} / \mathrm{cm}^{3}\right)$ & - & - \\
\hline & Insoluble & Insoluble \\
\hline Hot water & Insoluble & Insoluble \\
\hline Etnanor & Insoluble & Insoluble \\
\hline
\end{tabular}

${ }^{\text {abcd }}$ Means within the same row, not followed by same superscripts are significantly $(\mathrm{P} \leq 0.05)$ different 


\section{REFERENCES}

1. Dalziel JM The useful Plants of West Africa. Vol I and II. Crown Agent of the Colonies, London. 1948; 114-118.

2. Keay RWJ Trees in Nigeria. A Revised version of Nigerian Trees. Clarendon Press, Oxford. New York.1989; 195-197.

3. Mauron J Protein in Human Nutrition. Eds Rod, J.W.G. and Rolls B.A. Academic Press, New York. 1973; 1-2.

4. Altschul MA New Protein Foods. Technology. 1994; 4:1-30.

5. Circle JS and AK Smith Functional Properties of Commercial Edible Soya bean protein production. In 'Symposium': Seed Proteins. (Ed) G.E. Inglett Av. Publ. Co. Inc. Westport C.T. 1972. .

6. Olayanjo TMA Beniseed: A big treasure in small capsule. Publication in RMRDC. Raw Material Upgrade Magazine, Abuja. Nigeria. 2004.

7. Hojillaevangelist MP and RL Evangelista Functional properties of proteins in Lesquerella seed and press cake from oil processing[abstract]. American Oil Chemists' Society meeting. 2006; 108.

8. Mepba DH, Eboh $\mathbf{L}$ and SU Nwaojigwa Chemical composition and baking properties of wheat-plantain composite flours. African Journal of Food, Agriculture, Nutrition and Development. 2007; 7(1):21.

9. Pirie NW Food Protein Sources. In: the New Protein Sources International Biological Programme. 1975; 4. Pg. 49 - 104.

10. Pirie NW Leaf Protein and other aspects of Fodder Fractionation Ed. Cambridge University Press, London. 1978; 1-14.

11. Christie WW (Lipid Analysis Isolation, Separation, Identification Analysis of Lipids. $1^{\text {st }}$ Ed. Pergamon Press, Oxford. 1973; 46-120.

12. Terry DE, Agbaji AS and EB Agbaji Proximate composition of the seed Acacia nilotica and extraction of its protein. Tropical Science 1992; 32: 263 268.

13. AOAC. Association of Official Analytical Chemists, Official Methods of Analysis $16^{\text {th }}$ Ed. Horwitz. Washington D.C 1980.

14. Pearson D The Chemical analysis of Food. $7^{\text {th }}$ Ed. Church-Hill, Living Stone, London. 1976; 487-497. 
15. Paquot C Standard Methods for the Analysis of Oils, Fats, Derivatives. $6^{\text {th }}$ Ed. Part I (Sections I and II). 1979; 52-70.

16. Sathe SK, Deshpande SS and DK Salunkhe Functional Properties of Winged Bean (Psophocarpus tetragonolobus (L) DC) Proteins. Journal of Food Science. 1982; 47:544-549.

17. Okezie OB and AB Bello Physico-Chemical and Functional Properties of Winged Bean Flour and Isolate compared with Soy isolate. Journal of Food Science. 1988; 53(2): 450-454.

18. Lin MJY, Humbert ES and FW Sosulski Certain functional properties of sunflower meal products. Journal of Food Science. 1974; 39: 368.

19. Okaka JC and NN Potter Functional and storage properties of cowpea powder-wheat flour blends in breadmaking. Journal of Food Science. 1977; 42(3): 828-833. 